УДК 630.12.771.1.

\title{
ФУНКЦИОНАЛЬНАЯ РОЛЬ ЛЕКТИНОВ РАСТЕНИЙ КАК ПРЕДПОСЫЛКА ДЛЯ ИХ ПРИМЕНЕНИЯ В БИОТЕХНОЛОГИИ
}

\author{
(C) Н.Е. Павловская, И.Н. Гагарина*
}

Орловский государственный аграрный университет им. Н.В. Парахина, ул. Генерала Родина, 69, Орел, 302017 (Россия), e-mail: i-gagarina@list.ru

Цель данного обзора - обобщение современных данных по растительным лектинам и характеристика области их применеия в биотехнологии.

В обзоре приводятся современные данные о классификации лектинов, функциональной роли растительных лектинов, особенно бобовых, их токсичности, проблемах в питании и предпосылках использования в различных областях биотехнологического производства, в том числе для создания средств защиты от патогенов в растениеводстве и медицине.

Гликосвязывающие свойства и разнообразные молекулярные структуры, наблюдаемые в лектинах, обеспечили им широкий спектр биологической активности и наделили их способностью служить инструментом для биотехнологического применения.

Растительные лектины обладают многофункциональной ролью: участвуют в защитных реакциях клеток против патогенов и растительноядных насекомых, а также оказывают влияние на симбиоз с микроорганизмами, играя ключевую роль в установлении симбиотических отношений с клубеньковыми бактериями. Инсектицидные свойства лектинов находят применение в генной инженерии для создания устойчивых форм растений, защищающих от насекомыхвредителей, а также бактериальных и вирусных патогенов.

Взаимодействие лектинов с углеводами открывает перспективы применения их в таких важных областях, как иммунология, онкология и медицина, для диагностики и терапии различных заболеваний. Они также могут использоваться как маркеры и для определения групп крови.

Лектины, входя в состав белкового комплекса семян растений, в значительной степени снижают пищевые и кормовые достоинства многих культур и вызывают аллергию, это указывает на необходимость биотехнолгической переработки лектинсодержащих растений.

Ключевые слова: лектины, гемагглютинирующая активность, токсичные компоненты, роль в защитных реакциях, биотехнология, онкология.

Любой живой организм, включая человека, формируется за счет белков растительного и животного происхождения. Они входят в состав соединительных и костных тканей, выполняют динамическую, опорную функцию, обеспечивают взаимосвязь всех органов, их механическую целостность и защиту. Недостаток белка в пище человека вызывает физиологические и функциональные расстройства организма - задержку в росте и развитии, быструю физиологическую и особенно умственную утомляемость. Поэтому для восполнения недостатка белка и его получения рассматриваются как животные, так и растительные источники: кормовые и зерновые культуры и побочные продукты промышленного производства.

Однако продукты, полученные на основе растительных культур, могут содержать те или иные токсичные компоненты белковой природы (ингибиторы ферментов и лектины). Наиболее полно изучены белкиингибиторы протеолитических ферментов, в первую очередь трипсина. Высокое содержание ингибиторов в

Павловская Нинэль Ефимовна - доктор биологических наук, профессор, заведующая кафедрой биотехнологии, e-mail: ninel.pavlovsckaya@yandex.ru

Гагарина Ирина Николаевна - кандидат сельскохозяйственных наук, доцент кафедры биотехнологии, e-mail: i-gagarina@list.ru некоторых растениях приводит к значительному снижению пищевой ценности продуктов, полученных на их основе, так как они существенно затрудняют пищеварение белков. К токсичным компонентам растительной пищи относятся и белковые агглютинины - лектины.

\footnotetext{
* Автор, с которым следует вести переписку.
} 
Лектины были найдены во многих группах растений, в том числе одно- и двудольных, в съедобных плодах (банановые и томатные), луковицах (лук, чеснок, шалот), клубнях картофеля и семенах бобовых (coe, арахисе, конских бобах, нуте, фасоли, люпине, горохе и др.) [1-3], в различных тканях, таких как кора, листья, флоэмном соке, корневищах, кореньях, стеблях, культуре тканей, цветках и завязях. Они имеют различные клеточные локализации и молекулярные свойства. Больше всего лектинов содержится в растениях бобовых - сое, чечевице и фасоли, где они составляют до 2-3\% от общей массы белка. Лектины были изучены и в животном мире [4]. И на втором месте после растений по содержанию лектинов стоят морепродукты (угорь, моллюски, палтус и камбала).

Токсичность лектинов, как и ингибиторов протеиназ, приобретет особую актуальность, когда человечество столкнется с проблемой ограничения выбора источников пищевого белка, большая часть которых будет растительного происхождения. Больше всего вреда приносит лектин пшеничных зародышей. Поступивший с пищей лектин оседает на стенках кровеносных и лимфатических сосудов, стимулирует увеличение поджелудочной железы с одновременным уменьшением размеров тимуса (вилочковой железы), от деятельности которой зависит работа иммунной системы. Липкие молекулы лектина прилипают к слизистой поверхности кишечника, в частности, к ворсинкам (villi), повреждая их, способствуют неполноценному получению питательных веществ из пищи. Повреждая полезную микрофлору, лектины приводят к тому, что вредная токсичная микрофлора получает шанс размножиться [5]. Попадая при поедании пищи и корма в организм человека и животных, лектины могут ингибировать деятельность гормонов и ферментов пищеварительного тракта, индуцировать образование интерферона и лимфотоксинов, вызывать расстройство нервной системы, анафилаксию. Но самый большой вред лектинов в том, что они вызывают микроперфорацию стенок кишечника. Когда это случается, лектины и непереваренные частицы еды могут попадать в кровоток и разноситься по всему организму, вызывая воспаления и боли. Доктора называют это «синдром дырявой кишки» (lеаку gut) [6]. Поэтому лектины, входя в состав белкового комплекса семян, могут в значительной степени снижать пищевые и кормовые достоинства таких культур, как бобовые, где их особенно много.

По формулировке доктора Яна Коцурека, с которой согласны многие лектинологи, лектины - это белки, не относящиеся к классу иммунных (иммунные белки - иммуноглобулины - антитела), способные к обратимому связыванию с углеводной частью гликоконъюгатов без нарушения ковалентной структуры любых из узнаваемых гликозильных лигандов. Это взаимодействие с углеводами изучается в таких важных областях, как иммунология, онкология и медицина. Некоторые исследования показали способность этих молекул в распознавании клеток [7, 8].

В частности, они наделены бактерицидным действием по отношению к определенным видам патогенных бактерий, способны инактивировать действие некоторых вирусов, участвуют в регулировании иммунного ответа за счет активации системы комплемента. Считается, что система комплемента - древняя белковая система врожденного иммунитета - помогает распознавать чужеродные белки. Наряду с другими факторами она опирается на способность лектинов распознавать и связывать углеводы на поверхности клеточных мембран клеток-мишеней (т. е. клеток, на которые направлен удар иммунной системы). Способность лектинов активизировать ДНК лимфоцитов и агглютинировать их также определяется свойствами лектинов присоединять углеводы. Это наблюдали в опытах с лектинами фасоли, чечевицы обыкновенной, канавалии [9-11].

Для определения углеводной специфичности выявляют сахарид, отличающийся наиболее сильным ингибирующим эффектом, однако не для всех лектинов подобраны моно- или олигосахаридные ингибиторы. Лектины с одинаковой специфичностью по отношению к моносахаридам могут отличаться по сродству к ди-, полисахаридам и гликопептидам. На основании конкурентного анализа и данных аффинной хроматографии выделяют шесть классов лектинов, связывающих D-глюкозу или D-маннозу (1), ацетил-D-глюкозамин (2), ацетил-D-галактозамин (3), D-галактозу (4), 1-фруктозу (5) и смешанные углеводы (6) [12].

Термин «лектин» происходит от латинского слова Légère, что означает выбор [13]. Свойство обратимо связываться с конкретным моно- или олигосахаридом [14] является основным критерием классификации белка как растительного лектина. Кроме того, лектины могут также демонстрировать дополнительные сахара-связывающие домены, которые придают им различную биологическую активность [15].

До сих пор не существует единого мнения о классификации лектинов растений. В 1957 г. Мекеле сформировал одну из первых классификаций, основанную на их углеводной специфичности [13]. В 1998 г. 
была предложена новая система классификации лектинов из семи отдельных семей по сходству последовательностей и их эволюционных отношений [16].

Смешанные классификации основываются на соотношении белка и углеводов в молекуле лектина, валентности и числе субъединиц, происхождении, локализации источника выделения, функциональной активности, биологической активности и антигенной специфичности в отношении эритроцитов, лимфоцитов и других биологических объектов. По структурным особенностям лектины растений предложено делить на четыре класса: лектины бобовых, лектины с хитинсвязывающим доменом; белки RIPs, инактивирующие рибосомы; маннозоспецифичные лектины однодольных [2].

В настоящее время клеточные лектины подразделяются на 12 разных семейств с отчетливыми углевод-связывающими доменами: Agaricus двуспоровый, Amaranthins, класс V хитиназных гомологов, бересклет европейский, подснежник белоснежный, белки с Hevein доменами, jacalins, белки с легумин- доменами, белки доменных LysM, агглютинины семьи Nicotiana и рицин-B.

На сегодняшний день все растительные лектины принадлежат к одной из этих 12 семей, за исключением мальтоза-связывающего лектина, выделенного из Dioscorea batatas (DB3L), который не может быть классифицирован как лектин с точки зрения структуры и сахарной специфики. В список растительных лектинов входят рицин, абрин, ФГА, КонА-конковалин, WGA (wheat germ agglutinine) - агглютинин из проростков семян пшеницы и многие другие [13].

Многие выявленные растительные лектины, проявляющие характерную гемагглютинирующую активность, описаны в недавнем обзоре Van Damme [17].

В этом контексте классические лектины, из которых биохимические свойства были исследованы в основном с помощью их гемагглютинации, представлены в ряде растительных и животных лектинов, поделянных на следующие типы: R-тип (3), L-тип (11), C-тип (10), Р-тип (манноза-6-фосфат-связывающие) (12), (иммуноглобулины) (13), а также galectins (14). Этот вид номенклатуры (с некоторыми исключениями, такими как galectins) впервые был введен Дрикамера.

Лектины были выделены из растений, животных, бактерий и грибков [18-20]. Однако на сегодняшний день только несколько стероидов были выделены из грибов. Новый лектин (SRL) с молекулярной массой 38 кДа, а также уникальной IKSGVYRIVSWQGALGPEAR N-концевой последовательностью представляет собой первый лектин, выделенный из гриба, принадлежащего к роду Stropharia [21]. Он обладает характерной последовательностью N-концевой, углеводной специфичностью, относительно высокой термостойкостью и мощным антипролиферативным действием.

Для исследователей в настоящее время предоставляется доступ к фундаментальной информации о подробных олигосахаридных особенностях различных лектинов. В обзоре Jun Hirabayashi et.all. [22] aвторы описывают общедоступную базу данных о лектинах «Lectin Frontier Data Base (LfDB)», которая осуществляет постоянную публикацию и обновление полных данных о лектин-стандартах олигосахаридных взаимодействий с точки зрения констант диссоциации (KD-x). Для определения Кd используется система фронтальной аффинной хроматографии (FAC), с помощью которой были сформированы количественные наборы данных взаимодействий между иммобилизованными лектинами и 100 флуоресцентно меченных стандартных гликанов.

Система является уникальной в своей ясности, простоте процедуры и высокой чувствительности. Постоянное увеличение числа (более 67) ассоциированных публикаций свидетельствует о ее надежности. Таким образом, база данных о лектинах LfDB, будет играть важную роль в исследованиях лектинов, не только в основной, но и в прикладных областях науки об углеводах.

В настоящее время LfDB содержит более 180 данных о лектинах, среди которых 41 FAC данных, и данных анализов, полученных путем FAC в других лабораториях. В связи с этим, LfDB будет обновляться более широко не только за счет увеличения числа лектинов наборов данных, но и за счет реализации данных с использованием технологии Semantic Web в научно-исследовательской работе Resource Description Framework (RDF) [22, 23].

Известные биологические функции лектинов многочисленны. Они были рассмотрены M.J. Chrispeels, N.V. Raikhel, H. Rüdiger, H.-J. Gabius et all. [24, 25]. Они принимают участие в регуляции активности ряда ферментов, в том числе обуславливающих работу ионных насосов [26]; в формировании, поддерживании или использовании запасных питательных веществ [27]. Изучение биохимии, физиологии, цитологии и молекулярной биологии фитолектинов дает информацию по контролю их пространственного 
и временного размещения, по их клеточной и внутриклеточной локализации. По мнению А.А. Ямалеевой, достаточно много фитогемагглютининов ведут себя как типичные запасные белки, так как эти лектины, особенно обильно представленные либо в семенах, либо в разного типа вегетативных запасающих тканях, имеют такие же свойства, как и запасные белки. Например, в зрелых семенах фасоли фитогемагглютинины - второй по количеству запасной белок. Методом электрофореза в полиакриламидном геле проанализировано 602 электрофореграммы. Установлено, что между электрофоретической активностью фитогемагглютининов и фазеолином наблюдалась взаимосвязь, которую можно использовать как эволюционный маркер в истории культивирования вида [28].

Так как лектины часто сконцентрированы (как правило, 0,1-10\% от общего количества белка) в семенах или вегетативных органах (например, луковицы, кора и корневища), они, видимо, выполняют роль запасных белков, представляющих собой источник аминокислот для быстрого роста и развития [13, 29]. Данные показали, что большинство из лектинов накапливаются в вакуолях или родственных органеллах или секретируются внеклеточно [30]. Доказано, что лектины, которые, находятся в высоких концентрациях в клетках, участвуют в защитных реакциях клеток против патогенов и растительноядных насекомых, а также оказывают влияние на симбиоз с микроорганизмами [29, 31-33].

В отличие от высокоспецифичных лектинов, другая группа выявляется в конкретных условиях и при более низких концентрациях и, вероятно, участвует в каких-то иных функциях и механизмах [33]. В течение последнего десятилетия этот новый класс растительных лектинов, названный «индуцибильными лектинами», был тщательно изучен. При нормальных условиях роста или при отсутствии факторов стресса индуцибельные лектины не обнаруживаются. В отличие от классических лектинов, большинство индуцибельных лектинов остаются в ядре и цитоплазме растительной клетки [34]. Первый индуцибельный лектин был найден в рисовых саженцах, очищен и назван Oryza Sativa агглютинином (Orysata). Orysata является манноза-специфическим лектином, принадлежащим к джакалин-группе, он накапливается [29] во взрослых растениях и саженцах в ответ на засоление почвы или засуху. Позже Lannoo и другие [30] показали, что экспрессия лектина также индуцируется абсцизиновой и жасминовой кислотами.

Вместе с тем, как недавно выяснилось, лектины способны хранить информацию, осуществляемую углеводной составляющей, в связи с чем гликаны в настоящее время рассматривают как очень универсальную информационную платформу. Химические свойства лектинов обеспечивают углеводы, связывая определенные рецепторы. Связывающая способность углевода показана на примере позвоночных животных. Ее определяет большое количество сгибов белка. Sabine André и другие [35] исследовали структурную специфику лектина с помощью синтетической и надмолекулярной химии и создали программируемые модели поверхности клеток.

Как утверждает Н. Шарон, «специфика многих природных полимеров написана в сахарных остатках, а не в аминокислотах или нуклеотидах», хотя правила сахарного кода еще предстоит расшифровать [36]. По выражению Н. Rüdiger, H.-J. Gabius, «углеводы формируют третий алфавит жизни. По сравнению с аминокислотами и нуклеотидами их многосторонность для формирования изомера (кодовые слова) непревзойденна» [37]. Исследование биохимии углевода показало большой потенциал сахарного алфавита для кодирования [30].

По сравнению с большим количеством лектинов из других источников, описанных в литературе, широко распространены и хорошо изучены бобовые лектины. Фитогемагглютинины зерновых бобовых являются гетерогенными белками со сравнительно небольшим молекулярным весом порядка 53000110000. Их присутствие обнаружено в альбуминах, вицилинах, легуминах и подобных им глобулинах, в отдельных компонентах электрофоретических спектров. Они обычно состоят из двух или четырех субъединиц (25-30 кДа), каждый связывает один углевод. Взаимодействие с углеводами происходит через Са ${ }^{2+}$ и $\mathrm{Mn}^{2+}$ (или другой переходной металл) [1]. Их белковые первичные структуры обладают стойкими гомологиями, демонстрируя, что эти белки были сохранены в процессе эволюции. 3D-структуры бобовых лектинов схожи и характеризуются высоким содержанием бета-листов и отсутствием альфа-спиралей.

Какую роль они играют в семенах бобовых культур, еще предстоит выяснить. Однако, являясь резервными глобулинами, можно предположить, что бобовые лектины играют роль, связанную с хранением [1]. Запасные глобулины были подробно изучены в бобовых, особенно в горохе, сое, люпине, кормовых бобах и фасоли [38]. 
Растения являются наиболее доступным источником углевод-связывающих белков [16], участвующих в различных физиологических процессах [39]. Даже похожие друг на друга растительные лектины могут, тем не менее, различаться по биологической активности [40]. Принимая во внимание способность лектинов к избирательному связыванию с углеводами и с учетом этих белков в качестве сигнальных молекул, вызывающих разнообразные физиологические процессы в живых организмах, можно предположить, что они имеют существенный потенциал для широкого практического применения [41].

Существует несколько подходов для применения растительных лектинов: (I) не-иммобилизованные лектины могут быть использованы для изучения метаболических изменений в клетках и тканях (лечение болезней, защита растений от микроорганизмов, активация роста растений); (II) в качестве зондов меченых лектинов (анализ углеводов, диагностика заболеваний); (III) иммобилизованные лектины (хроматография) (анализ лектинов, диагностика заболеваний); (IV) перенос лектиновых генов в растительный геном, который может обеспечить защиту растений от биотических и абиотических стрессов, регулировать рост растений и образование растительно-микробных систем [41], повышать активность почвы микроорганизмами [42], повышать и стабилизировать ферменты при тепловой инактивации [43].

Для практического использования получают новые лектины с широким спектром полезных свойств из растительных источников, с помощью мутагенеза, и генной инженерии (рекомбинантный лектин) [44]. Генная инженерия растений по внедрению генов лектинов является перспективным способом увеличения продуктивности растений в будущем, если спор по поводу использования трансгенных растений в сельском хозяйстве решится в пользу последних.

Показано также, что, например, лектины сои могут выступать в качестве гликопротеиднобактериального препарата, способного улучшить азотфиксирующую активность у бобовых культур [42] и увеличить продуктивность растений. Установлено, что лектины играют ключевую роль в установлении симбиотических отношений с клубеньковыми бактериями, что связано со способностью гликопротеиновых белков индуцировать метаболические изменения в бактериальных клетках и усиливать адгезию микроорганизмов к поверхности корня [39]. Роль лектинов в симбиозе с клубеньковыми бактериями была подтверждена генно-инженерными экспериментами: клевер, которому пересадили ген лектина гороха, лядвенец рогатый (Lotus corniculatus), которому пересадили ген одного из лектинов сои, начали вступать в симбиоз с клубеньковыми бактериями, с которыми они в норме в симбиоз не вступают. Эти и другие эксперименты не только доказали роль лектинов в распознавании бактериального симбионта, но и показали, что процесс опознания является сложным и многоступенчатым [45].

Обзорная статья Ф.М. Шакировой и М.В. Безруковой [46], посвященная функциям лектинов растений, показывает, что они играют большую роль в межклеточных взаимодействиях с другими организмами, безошибочно «узнают» азотфиксирующие бактерии - ризобии и активно участвуют в формировании и регуляции симбиотических взаимоотношений с ними.

Вместе с тем лектины играют важную роль в механизмах защиты растений от вредителей и болезней. Так, они могут проявлять значительный синергетический эффект при слиянии двух и более лектинов в качестве биологически активных соединений благодаря совмещению в себе полезных свойств всех компонентов, из которых они состоят [47]. Например, ассоциация двух лектинов показала сильное ингибирующее действие на развитие личинок. В частности, показана роль лектинов в защите растений от насекомых (Coleoptera, Homoptera, Diptera и Lepidoptera) [48, 49] и грибов.

Работа Ana C. Ribeiro [1] дает экспериментальное доказательство того, что активностью лектинов обладают и бобовые вицилины, которые относятся к другому обширному специализированному классу лектинов в семенах бобовых, обозначенных как семья II. Автор представила доказательства, основанные на усовершенствованной методологии, разработанной для идентификации новых лектинов [51]. Результаты, полученные для трех вицилинов, показывают, что все они содержат полипептиды, которые специфически связываются с углеводами, что было подтверждено с помощью иммуноблоттинга с использованием специфических поликлональных антител против каждого из очищенных вицилинов, установлено, что связанные полипептиды имеют молекулярные массы в диапазоне от 56 до 31 кДа ( $\beta$-conglutin), 64 до 41 кДа (В. Конский вицилин) и от 73 до 13 кДа ( $\beta$-lathyrin).

V.M. Gomes и соавторы [50] сообщили, что вицилины оказались токсичными для семейства жесткокрылых и чешуекрылых, так как они подавляют развитие личинок. Они также ингибируют рост дрожжей, и их связывание с дрожжевыми клетками является опосредовано со специфическим связыванием с хити- 
ном грибковой клеточной стенки [50]. Этой хитинсвязывающей способностью объясняется действие фунгицидов и инсектицидов, относящихся ко многим представителям белков-вицилинов.

B обзоре Renata de Oliveira Dias et. all [52], посвященном источникам животных и растительных лектинов, описывается не только их функциональная классификация и трехмерная структура, но и связь этих свойств с биотехнологическими возможностями, в том числе противомикробными мероприятиями. Структурно-функциональные различия лектиновых групп проливают некоторый свет на взаимодействия хозяина-патогена. Также рассматривается возможность их применения в качестве биотехнологических инструментов в генной инженерии и разработке новых лекарств.

Доказано, что лектины ингибируют рост некоторых фитопатогенных и непатогенных грибов [53, 54]. Мишенью некоторых растительных лектинов являются грибки, которые имеют хитин в своих клеточных стенках, а также они вовлечены в защиту против оомицетов. Роль этих лектинов в сопротивлении Phytophtora infestans связывают с наличием активатора фитофтороза, который лектин преобразовывает в гиперчувствительную реакцию [55], а также усиливает клеточную стенку и плазматическую мембрану после заражения [56]. Различные лектины участвуют в сопротивлении Резуховидки Таля (Arabidópsis thaliána) грибковым инфекциям [57-59], а лектин Рицин В может играть определенную роль в защите растений от патогенов, насекомых и вирусов [60]. Ф.М. Шакировой [46] приведены результаты, свидетельствующие об участии лектина зародыша пшеницы АЗП в формировании ответных реакций при заражении возбудителями корневой гнили и септориозом, что может говорить о вовлечении лектина в развитие устойчивости пшеницы к различным грибным болезням и реальной возможности выполнения им защитной функции.

По данным Н.Е. Павловской и И.Н. Гагариной, лектины, выделенные из семян бобовых культур (фасоли, гороха, сои), обладают фунгицидными свойствами против возбудителя корневых гнилей гороха Fusarim oxysporum [61]. На основе лектинов создан препарат [62], обладающий иммунномодулирующими свойствами, который не только повышает устойчивость гороха к возбудителю корневых гнилей, но и снижает применение химических пестицидов [63].

Сельскохозяйственные потери от болезней и вредителей являются сложной экономической и продовольственной проблемой. Глобальная продовольственная безопасность находится под угрозой в связи с ростом численности населения, появлением и распространением вредителей, значительно увеличивается с изменением климата [64]. Стратегия по преодолению ущерба, причиненного патогенами, включает химическую обработку, традиционную селекцию и трансгенные подходы [65]. Начиная с 1980 г. была предложена и испытана новая стратегия борьбы с вредителями, такая как комплексная борьба (IPM - Интегрированная борьба с вредителями), и использование трансгенных культур во избежание потерь сельскохозяйственных культур. Трансгенные растения, экспрессирующие гены лектинов, были получены для повышения устойчивости против нематод и насекомых [33].

Эффект действия лектинов при проглатывании личинками насекомых выражается в задержке роста, снижении размера и веса, вмешательстве в плодовитость самок, а также в снижении окукливания и проценте имаго, а в некоторых случаях приводит к смерти личинок насекомых. Так, соевый лектин (SBL) вводили в растения табака с помощью Agrobacterium-опосредованной трансформации, улучшая устойчивость к инфекции против Phytophthora nicotianae [33]. Другим примером является экспрессия гена агглютининов Pinellia ternata в хлоропласты табака [66]. Такая генная инженерия привела к значительной устойчивости растений против белокрылки, тли, чешуекрылых и бактериальных и вирусных патогенов.

Лектины способствуют формированию устойчивости растения к заражению микроорганизмами аналогично иммунной системе иммунокомпетентных организмов. Растительные лектины способны инактивировать вирусы различных таксономических групп, связывая углеводные остатки их оболочек. Так, механизм антивирусного действия лектинов растений рода каланхоэ (Kalanchoe Adans) состоит в непосредственном склеивании вирусных частиц, изменении их морфологии и торможении адсорбции вирусов на поверхности клеток [67]. Высказаны предположения о связи между активированием механизма антивирусной защиты растений и изменением активности фитогемагглютининов [68] и о том, что агглютинирующие белки клубней картофеля принимают участие в формировании механизмов их устойчивости к вирусам и вредителям.

Действие лектинов может быть избирательно и, как указывают Д.М. Сытников, С.Я. Коць [69], например, АЗП, лектины сои и гороха обладают фунгитоксической активностью по отношению к грибам Fusarium и бактериям Erwinia, но не влияют на рост Alternaria sp. При этом эффект фунгитоксического действия лектинов определяется также их концентрацией [70], а также химическим строением. Например, 
многие растения содержат лектины, имеющие сродство к $\mathrm{N}$-ацетил-D-глюкозамину и олигомерам хитина, поэтому они могут взаимодействовать с грибами и насекомыми, содержащими хитин, через ферменты хитиназу, анионную пероксидазу и оксалатоксидазу [15, 71, 72].

Как отмечают О.В. Кириченко, В.Г. Сергиенко [70], высокая концентрация лектинов в семенах и коре может быть токсичной для животных. Среди растений широко распространены белки, составляющие группу так называемых рибосоминактивирующих белков (rips), многие из которых являются агглютининами и высокотоксичными веществами (рицин, абрин, модецин и др.), и, очевидно, участвуют в защите растения от других организмов $[11,15]$.

Функции лектинов не ограничиваются участием в межклеточных взаимодействиях и защите растений от биотических стрессоров. В последние годы появились данные об участии лектинов в реакциях растений на неблагоприятные условия внешней среды, при различных абиотических стрессах. Выяснению их физиологической роли в этом случае может способствовать изучение свойств и распределения лектинов в мембранных структурах растительной клетки [64].

Рассматривая возможности использования лектинов в биотехнологии, Renata de Oliveira Dias et. all [52] приводит отчеты K. Ueno, M. Sarkar, L.G. Monte, B. Nelson, I. Yazgan и других, описывающих применение различных лектинов для оценки клеточных поверхностей для типирования крови, контроля биосинтеза, межклеточных взаимодействий в иммунной системе и связь с восприимчивостью к разнообразным инфекционным и аутоиммунным заболеваниям.

Кроме того, лектины могут также применяться в лабораторных и химических анализах. Например, реакция агглютинации лектинами других клеток организма способствует использованию их для определения групп крови (они обладают способностью распознавать три типа эритроцитов - A, B, O).

Лектины, содержащиеся в продуктах питания, - одна из основных причин нарушения хрупкого равновесия желудочно-кишечного тракта. Действие лектинов, имеющих белковую природу, зависит от группы крови [64]. Если в пище, которую мы едим, содержатся несовместимые с вашей группой крови лектины, то они будут нарушать работу желудочно-кишечного тракта и иммунной системы, а также обмен веществ.

Ученые сегодня приписывают лектинам также свойство вызывать аллергические реакции, т. е. делают их ответственными за пищевые аллергии. Многие люди страдают непереносимостью глютена - наиболее известного из пшеничных лектинов, воздействующего на клетки внутренней оболочки тонкого кишечника, вызывая раздражение и воспаление тканей. Предполагается, что причиной этого является нарушение микробиологического равновесия в желудочно кишечном тракте, угнетение бактерий-симбиотов (бифидумбактерий, лактобактерий, дружественных видов кишечной палочки) гельминтами, вирусами, грибками, антибиотиками, бродильными и гнилостными бактериями.

Пищевые лектины, взаимодействующие с тканями желудочно-кишечного тракта, стимулируют выработку гистамина вещества, вызывающего симптомы аллергии. Лектины и сами являются основной причиной пищевой аллергии. Они повышают проницаемость стенок кишечника и повреждают его внутреннюю оболочку. Лектины и крупные белковые молекулы - аллергены попадают в кровь и разрушительно действуют на организм [73].

Поэтому людям, страдающим заболеваниями пищеварительной системы (колит, болезнь Крона и др.) не стоит увлекаться бобовыми, арахисом, цельнозерновым хлебом, проростками пшеницы и другими продуктами, содержащими семена или зерна растений, где лектины находятся в больших концентрациях [74].

Вместе с тем, к воздействию пищевых лектинов очень чувствительна нервная ткань. Некоторые исследователи обратили внимание, что низкоаллергенное питание оказывает положительный эффект при ряде неврологических расстройств, в том числе нарушении активности и внимания у детей. Не исключено, что свой вклад в улучшение состояния больных при этом вносит и одновременное уменьшение количества лектинов, попадающих в организм. Российские исследователи обратили внимание на то, что при шизофрении ткани мозга становятся более чувствительными к воздействию некоторых лектинов, содержащихся в популярных продуктах питания [73].

Особенно опасны лектины бобовых культур. Так, лектины очищенных бобов или сои влияют на рост крыс и вызывают удлинение тонкой кишки, стимулируя гипертрофию и гиперплазию поджелудочной железы [75]. Кроме того, лектины бобовых могут снижать рост клеток или влиять на усвоение питательных веществ, некоторые из них являются смертельными, если они попадают в организм в высоких концентрациях [76]. 
Одним из наиболее распространенных нарушений в западном мире является пищевая аллергия. В последние десятилетия распространенность пищевой аллергии увеличились в некоторых регионах по всему миру [77, 78]. В связи с этим в настоящее время существует законодательство по маркировке продуктов, вызывающих пищевую аллергию, основанное на списке Codex Alimentarius 1999 г. [79, 80].

Вместе с тем, лектины имеют важное значение в различных аспектах медицинского применения. Так, они играют в организме роль неких биосенсоров, способных распознавать и деструктировать биопленки патогенов (чужеродных и патологически измененных клеток) [81], что дает возможность фармацевтической промышленности модифицировать многие противобактериальные, противогрибковые и противовирусные лекарственные препараты, а также идентифицировать возбудителей инфекционных заболеваний.

В последние годы при изучении токсичности некоторых лектинов выяснилось, что они оказывают влияние на клетки рака. Было обнаружено, что клетки рака толстой кишки человека CCL-220/Colo320 DM соединяются с агглютинином из фасоли Phaseolus vulgaris (PHA-L) и зародышей пшеницы (WGA), в то время как нормальные клетки CRL-1459/CCD-18Cо такими свойствами не обладают [82]. Имеется информация о том, что важным с точки зрения медицины свойством обладают также лектины сои, отличающиеся от лектинов других растений тем, что они ингибируют связывание кальцитоцина с клетками рака молочной железы человека. Это свойство является одной из причин широкого использования лектинов семян сои при лечении онкологических заболеваний, в первую очередь рака молочной железы.

Кроме того, соевые лектины являются важным фактором при лечении рака крови, так как связываются с пораженными гликопротеинами крови, не затрагивая нормальные гликопротеины, что происходит вследствие их сродства с аномальной углеводной частью пораженных клеток [83]. Питер д’Адамо пишет: «Соевые лектины способны селективно обнаруживать самые первые мутированные клетки, вырабатывающие А-антиген, и удалять их из организма, не затрагивая здоровые клетки».

Лектины зародышей пшеницы являются высоко токсичными для клеток карциномы поджелудочной железы человека, вызывая фрагментацию и высвобождение ДНК, что аналогично апоптозу. С другой стороны, было также установлено, что раковые клетки из стромы человека, получавшие лектины, имеют повышенную адгезию к основанию, в отличие от тех, которые не получали лектины [84], что говорит о селективности лектинов на различные линии клеток рака. Свойства лектинов распознавать углеводные соединения на поверхности клеток опухолей открывают перспективы эффективного воздействия на их элиминацию (выведение из организма).

Между тем многие растительные лектины применяются в лечении ряда других заболеваний. Так, семена бобовых растений, особенно богатые лектинами, имеют высокую степень гомологии структур, различающихся в основном их четвертичной структурой, что обеспечивает их различные биологические свойства. Pinto и другие [85] показали, что лектин B. Variegata обладает противовоспалительным свойством, активируя иммунные клетки и стимулируя реакцию заживления в естественных условиях. Этот лектин при использовании в лечении кожных ран у мышей был ответственным за реконструкцию эпителия и увеличение отложения кератина, указывая на улучшение заживление ран. Фибробласты — клетки соединительной ткани организма, секретируя предшественники белков коллагена и эластина, а также мукополисахариды, имеют важное значение для заживления кожных ран, особенно на ранних стадиях заживления. Стимуляция их пролиферации является механизмом, с помощью которого терапевтические агенты могут инициировать заживление [86]. Ученые Белоруссии провели исследования, связанные с наличием лектинов в составе ряда лекарственных растений, разрешенных Министерством здравоохранения Республики Беларусь к практическому использованию, и анализом ресурсного потенциала наиболее перспективных представителей [87]. В результате была установлена вариабельность показателя фитогемагглютинирующей активности лекарственных растений различных систематических групп дикорастущей флоры Беларуси в зависимости от вида и локализации в органах растений. Наибольшая величина ФГА была отмечена в плодах и корнях, минимальные значения данного показателя были характерны в основном для листьев и цветков исследованных растений. По величине показателя активности ФГА в корнях растения располагались следующим образом: Taraxacum officinale $>$ Plantago major $>$ Trifolium pratense $>$ Chelidonium majus $>$ Elytrigia repens, что позволяет рассматривать их в качестве возможных источников лектинов.

Выявлены оптимальные сроки сбора наиболее перспективного лекарственного сырья Taraxacum officinale с целью выделения лектинов. Показано модулирующее действие препаратов лектинов Cetraria islandica и Taraxacum officinale на функциональную активность альвеолярных макрофагов; ЕК (естественные кил- 
лерные клетки), и Т-клеток (Т-лимфоцита) и клеток рака молочной железы. Влияние препарата лектина из корней Taraxacum officinale на опухолевые клетки оценивали по их жизнеспособности и активности в них фермента ацетилхолинэстеразы (АХЭ). Проведенный анализ ресурсного потенциала Cetraria islandica и Taraxacum officinale позволяет более рационально использовать имеющиеся запасы растительного сырья указанных растений с целью получения отечественных препаратов медицинского назначения.

Кроме выше сказанного, в настоящее время разрабатываются следующие прикладные аспекты использования лектинов: применение в цито- и гистохимии для характеристики гликопротеинов и других гликоконьюгатов в норме и патологии; биохимический и структурный анализы клеточных и тканевых гликопротеиназ; выявление групповых аллоантигенов (другие антигены у генетически различающихся особей одного вида) в гематологии и судебной медицине; исследование механизмов взаимодействия макромолекул и клеток, а также процессов распознавания на молекулярном уровне. К сожалению, несколько меньшее внимание уделяется разработке вопросов физиологической роли лектинов в различных биологических системах.

\section{Заключение}

Таким образом, из обзора литературы следует, что лектины представляют собой разнородную группу поливалентных белков неиммунного происхождения, которые распознают и обратимо связывают различные углеводные структуры (моносахариды, олигосахариды и гликоконъюгаты), не изменяя их.

Классификация лектинов основана на их специфичности, биохимических свойствах, биологическом распространении, углевод-связывающих доменах. В настоящее время имеется доступная информация в базах данных геномов (Lectin Frontier DataBase (LfDB)), которая осуществляет непрерывную публикацию и обновление полных данных о лектинах.

Растительные лектины обладают многофункциональной ролью: участвуют в защитных реакциях клеток против патогенов и растительноядных насекомых, а также оказывают влияние на симбиоз с микроорганизмами, способны инактивировать вирусы различных таксономических групп, связывая углеводные остатки их оболочек. Лектины способны хранить информацию, осуществляемую углеводной составляющей. Исследование биохимии углевода показали большой потенциал сахарного алфавита для кодирования.

Гликосвязывающие свойства и разнообразные молекулярные структуры, наблюдаемые в этих классах белков, обеспечили им широкий спектр биологической активности и сделали их объектом биотехнологического применения. Существует несколько подходов для применения растительных лектинов: изучение метаболических изменений в клетках и тканях (лечение болезней, защита растений от микроорганизмов, активация роста растений); в качестве зондов меченых лектинов (анализ углеводов, диагностика заболеваний); иммобилизованные лектины (хроматография) (анализ лектинов, диагностика заболеваний); перенос лектиновых генов в растительный геном, который может обеспечить защиту растений от биотических и абиотических стрессов, а также регулировать рост растений и образование растительно-микробных систем.

Реакция агглютинации лектинами других клеток организма способствует использованию их для определения групп крови (они обладают способностью распознавать три типа эритроцитов - А, В, О).

Лектины играют важную роль в укладке белка, межклеточной адгезии, хозяин-патогенвзаимодействий и клеточной сигнализации, являются потенциальными мишенями для разработки противовирусных препаратов и вакцин и рассматриваются в качестве мишеней лекарственных средств. Лектины нашли свое приложение во многих биологических науках, таких как таксономические, эмбриологические и бактериологические исследования, исследования рака, сортировка клеток, сортировка мутантных и опухолевых клеток и выделение мембранных и сывороточных гликоньюгатов и т.д. Инсектицидные свойства лектинов используют в генной инженерии для создания устойчивых форм растений (к белокрылке, тле, чешуекрылым и бактериальным и вирусным патогенам).

\section{Список литературы}

1. Ana C. Ribeiro, Sara V. Monteiro, Belmira M. Carrapiço, Ricardo B. Ferreira. Are Vicilins Another Major Class of Legume Lectins // Molecules, 2014. Vol. 19. Pp. 20350-20373.

2. Van Dame J.M., Peumans W.J., Pustai A., Bardocz S. Handbook of plant lectins: properties and biomedical applications. Chichester etc.: John Willey and Sons, 1998. P. 451.

3. Rüdiger H., Gabius H., Review J. Plant lectins: Occurrence, biochemistry, functions and applications // Glycoconjugate. 2001. Vol. 18. Pp. 589-613. 
4. Sandro Mascena Gomes Filho, Juscélio Donizete Cardoso, Katya Anaya, Edilza Silva do Nascimento, José Thalles Jucelino Gomes de Lacerda, Roberto Mioso, Tatiane Santi Gadelha, Carlos Alberto de Almeida Gadelha. Lectins actual status on properties and biological activities // Molecules. 2015. Vol. 20. Pp. 348-357.

5. Eri Kenmochi, Syed Rashel Kabir, Tomohisa Ogawa, Ryno Naude, Hiroaki Tateno, Jun Hirabayashi, Koji Muramoto. Isolation and Biochemical Characterization of Apios Tuber Lectin // Molecules. 2015. Vol. 20. Pp. 987-1002.

6. Лектины [Электронный ресурc]. URL: http://www.horosheezdorovje.ru/lektiny-1/.

7. Komath S.S., Kavitha M., Swamy M.J. Beyond carbohydrate binding: new directions in plant lectin research // Organic Biomolecular Chemistry. 2006. Vol. 4. Pp. 973-988.

8. Игнатов В.В. Углеводузнающие белки - лектины // Биология (Соровский образовательный журнал). 1997. №2. C. 15-20.

9. Косенко Л.В. Сортовые различия углеводсвязывающих свойств лектинов из семян Vicia Jabe // Физиология растений. 2002. Т. 49. №6. С. 859-864.

10. Косенко Л.В. Сравнительная характеристика углеводсвязывающих свойств лектинов из семян бобовых растений // Физиология растений. 2002. Т. 49. №5. С. 718-724.

11. Kass H. Some properties of carbohydrate bilding protein (lectins) solubilizied from cell wall of Phaseolis aureus // Planta. 1996. Vol. 130. N2. Pp. 169-214.

12. Марков Е.Ю., Хавкин Э.Е. Лектины растений: предполагаемые функции // Физиология растений. 1983. Т. 30, вып. 5. C. 852-867.

13. Maria Lígia R., Macedo, Caio F.R., Carolina T. Oliveira Insecticidal Activity of Plant Lectins and Potential Application in Crop Protection // Molecules. 2015. Vol. 20. Pp. 2014-2033

14. Peumans W.J., van Damme E. Lectins as plant defense proteins // Plant Physiol. 1995. Vol. 109. Pp. 347-352

15. Van Damme E.J., Lannoo N., Fouquaert E., Peumans W.J. The identification of inducible cytoplasmic/nuclear carbohydrate-binding proteins urges to develop novel concepts about the role of plant lectins // Glycoconj. 2003. Vol. 20. Pp. 449-460

16. Van Damme E.J.M., Peumans W.J., Barre A., Rouge P. Plant lectins: A composite of several distinct families of structurally and evolutionary related proteins with diverse biological roles // Crit. Rev. Plant Sci. 1998. Vol. 17. Pp. 575-692.

17. Antonyuk V.O. Lectins and their stock sources. Lviv, 2005. 554 p.

18. Zhao J.K., Wang H.X., Ng T.B. Purification and characterization of a novel lectin from the toxic wild mushroom Inocybe umbrinella // Toxicon. 2009. Vol. 53. Pp. 360-366.

19. Li Y.R., Liu Q.H., Wang H.X., Ng T.B. A novel lectin with potent antitumor, mitogenic and hiv-1 reverse transcriptase inhibitory activities from the edible mushroom // Glycoconjugate Journal. 2010. Vol. 27. Pp. 259-265

20. Zhang G., Sun J., Wang H., Ng T.B. First isolation and characterization of a novel lectin with potent antitumor activity from a Russula mushroom // Phytomedicine. 2010. Vol. 17. Pp. 775-781.

21. Weiwei Zhang, Guoting Tian, Xueran Geng, Yongchang Zhao, Tzi Bun Ng, Liyan Zhao and Hexiang Wang. Isolation and Characterization of a Novel Lectin from the Edible Mushroom Stropharia rugosoannulata // Molecules. 2014. Vol. 19. Pp. 19880-19891

22. Jun Hirabayashi, Hiroaki Tateno, Toshihide Shikanai, Kiyoko F. Aoki-Kinoshita and Hisashi Narimatsu. The Lectin Frontier Database (LfDB), and Data Generation Based on Frontal Affinity Chromatography // Molecules. 2015. Vol. 20. Pp. 951-973

23. Aoki-Kinoshita K.F., Bolleman J., Campbell M.P., Kawano S., Kim J.D., Lütteke T., Matsubara M., Okuda S., Ranzinger R., Sawaki H. Introducing glycomics data into the Semantic Web. J. // Biomedical Semantics. 2013. Vol. 4. P. 39.

24. Rüdiger H., Gabius, H.J. Plant lectins. in the sugar code // Fundamentals of Glycosciences. 2009. Pp. 301-315.

25. Chrispeels M.J., Raikhel N.V. Lectins, lectins genes and their role in plant defense // Plant Cell. 1991. Vol. 3. Pp. 1-9.

26. Bowles D.J. Distribution of lectins in membranes of soybean in root, shood and leaftissues at differetnt stades of growth // Planta. 1997. Vol. 145. N2. P. 193.

27. Kilpatric D.C., Vcomen M.M., Gould A.R. Tissue and subcellular distribution of the lectin from Datura stramonium (thom apple ) // Biochem. J. 1979. Vol. 2. P. 215.

28. Ямалеева А.А. Лектины растений и их биологическая роль. Уфа, 2001. 137 с.

29. Michiels K., van Damme E., Smagghe G. Plant-insect interactions: What can we learn from plant lectins? // Arch. Insect Biochem. Physiol. 2010. Vol. 73. Pp. 193-212.

30. Lannoo N., van Damme E.J.M. Nucleocytoplasmic plant lectins. Biochim. Biophys // Acta Gen. Subj. 2010. Pp. 190-201

31. Al Atalah B., Smagghe G., van Damme E.J.M. Orysata, a jacalin-related lectin from rice, could protect plants against biting-chewing and piercing-sucking insects // Plant Sci. 2014. Pp. 221-222.

32. Roy A., Gupta S., Hess D., Das K.P., Das S. Binding of insecticidal lectin Colocasia esculenta tuber agglutinin (CEA) to midgut receptors of Bemisia tabaci and Lipaphis erysimi provides clues to its insecticidal potential // Proteomics. 2014. Vol. 14. Pp. 1646-1659.

33. Guo P., Wang Y., Zhou X., Xie Y., Wu H., Gao X. Expression of soybean lectin in transgenic tobacco results in enhanced resistance to pathogens and pests // Plant Sci. 2013. Vol. 211. Pp. 17-22

34. Peumans W.J., Barre A., Hao Q., Rougé P., van Damme E.J.M. Higher plants developed structurally different motifs to recognize foreign glycans // Trends Glycosci. Glycotechnol. 2000. Vol. 12. Pp. 83-101. 
35. Sabine André, Herbert Kaltner, Joachim C. Manning, Paul V. Murphy, Hans-Joachim Gabius Lectins. Getting Familiar with Translators of the Sugar Code // Molecules. 2015. Vol. 20. Pp. 1788-1823

36. Sharon N. Glycoproteins now and then: A personal account // Acta Anat. 1998. Vol. 161. Pp. 7-17.

37. Rüdiger H., Gabius H.-J. The biochemical basis and coding capacity of the sugar code // In The Sugar Code. Fundamentals of Glycosciences. 2009. Pp. 3-13.

38. Shewry P.R., Napier J.A., Tatham A.S. Seed storage proteins: Structures and biosynthesis // Plant Cell. 1995. Vol. 7. Pp. 945-956.

39. Kovalchuk N.V., Melnykova N.M., Musatenko L.I. Role of phytolectins in the life cycle of plants // Biopolym. Cell. 2012. Vol. 3. Pp. 171-180.

40. Benoist H., Culerrier R., Poiroux G., Segui B., Jauneau A., Van Damme E.J., Peumans W.J., Barre A., Rouge P. Two structurally identical mannose-specific jacalin-related lectins display dif-ferent effects on human T lymphocyte activation and cell death // J. Leukoc. Biol, 2009. Vol. 1. Pp. 103-114.

41. Melnykova N.M., Mykhalkiv L.M., Mamenko P.M., Kots S.Ya. The areas of application for plant lectins // Biopolymers and Cell. 2013. Vol. 29. N5. Pp. 357-366

42. Kirichenko E.V., Titova L.V. Soybean lectin as a component of a composite biopreparation involving Bradyrhizobium japonicum // Prikl. Biokhim. Mikrobiol. 2006. Vol. 2. Pp. 219-223.

43. Alenkina S.A., Zharkova V.R., Nikitina V.E. Stabilizing effect of Azospirillum lectins on beta-glucosidase activity // Prikl. Biokhim. Mikrobiol. 2007. Vol. 6. Pp. 653-656.

44. Fernandezdel-Carmen A., Juarez P., Presa S., Granell A., Orzaez D. Recombinant jacalinlike plant lectins are produced at high levels in Nicotiana benthamiana and retain agglutination activity and sugar specificity // Biotechnol. 2013. Vol. 4. Pp. 391-400.

45. Бабош А. В. Лектины и проблема распознавания фитопатогенов растением-хозяином // Журнал общей биологии. 2008. Т. 69. №5. С. 379-396.

46. Шакирова Ф.М., Безрукова М.В. Современные представления о предполагаемых функциях лектинов растений // Журнал общей биологии. 2007. Т. 68. №2. С. 109-125.

47. Zhu-Salzman K., Ahn J.E., Salzman R.A., Koiwa H., Shade R.E., Balfe S. Fusion of a soybean cysteine protease inhibitor and a legume lectin enhances antiinsect activity synergistically // Agric. Forest Enthomol. 2003. Vol. 4. Pp. 317-323.

48. Tinjuangiun P., Loe N.T., Gatehouse A.M.R., Gatehouse J.A., Christou P. Enhanced insect resistence in Thai rice varieties generated by particle bombardment // Mol. Breed. 2000. Vol. 6. Pp. 391-399.

49. $\mathrm{Ng} \mathrm{T.B.} \mathrm{Review.} \mathrm{Antifungal} \mathrm{proteins} \mathrm{and} \mathrm{peptides} \mathrm{of} \mathrm{leguminous} \mathrm{and} \mathrm{non-leguminous} \mathrm{origins} \mathrm{//} \mathrm{Peptides.} 2004$. Vol. 25. Pp. 1215-1222.

50. Gomes V.M., Okorokov L.A., Rose T.L., Fernandes K.V.S., Xavier-Filho J. Legume vicilins (7S storage globulins) inhibit yeast growth and glucose stimulated acidification of the medium by yeast cells // Biochim. Biophys. Acta. 1998. Pp.207-216.

51. Ribeiro A., Catarino S., Ferreira R.B.F. Multiple lectin detection by cell membrane affinity binding // Carbohyd. Res. 2012. Pp. 206-210.

52. Renata de Oliveira Dias, Leandro dos Santos Machado, Ludovico Migliolo, Octavio Luiz Franco. Insights into Animal and Plant Lectins with Antimicrobial Activities // Molecules. 2015. Vol. 20. Pp.519-541.

53. Miyakawa T., Hatano K.-I., Miyauch, Y., Suwa Y.-I., Sawano Y., Tanokura M. A secreted protein with plant-specific cysteine-rich motif functions as a mannose-binding lectin that exhibits antifungal activity // Plant Physiol. 2014. Vol. 166. Pp.766-778.

54. Ang A.S.W., Cheung R.C.F., Dan X., Chan Y.S., Pan W., Ng T.B. Purification and characterization of a glucosamine-binding antifungal lectin from Phaseolus vulgaris cv. Chinese pinto beans with antiproliferative activity towards nasopharyngeal carcinoma cells // Appl. Biochem. Biotechnol. 2014. Vol. 172. Pp. 672-686.

55. Kanzaki H., Saitoh H., Takahashi Y., Berberich T., Ito A., Kamoun S., Terauchi R. NbLRK1, a lectin-like receptor kinase protein of Nicotiana benthamiana, interacts with Phytophthora infestans INF1 elicitin and mediates INF1induced cell death // Planta. 2008. Vol. 228. Pp. 977-987.

56. Bouwmeester K., de Sain M., Weide R., Gouget A., Klamer S., Canut H., Govers F. The lectin receptor kinase LecRK-I.9 is a novel Phytophthora resistance component and a potential host target for a RXLR effector. PLoS Pathog, 2011. $327 \mathrm{p}$.

57. Huang P., Ju H.-W., Min J.-H., Zhang X., Kim S.-H., Yang K.-Y., Kim C.S. Overexpression of L-type lectin-like protein kinase 1 confers pathogen resistance and regulates salinity response in Arabidopsis thaliana // Plant Sci. 2013. Vol. 203. Pp. 98-106.

58. Singh P., Chien C.-C., Mishra S., Tsai C.-H., Zimmerl L. The arabidopsis lectin receptor kinase-VI. 2 is a functional protein kinase and is dispensable for basal resistance to Botrytis cinerea. Plant Signal. Behav, 2012.611 p.

59. Singh P., Kuo Y.-C., Mishra S., Tsai C.-H., Chien C.-C., Chen C.-W., Desclos-Theveniau M., Chu P.-W., Schulze B., Chinchilla D. The lectin receptor kinase-VI.2 is required for priming and positively regulates arabidopsis patterntriggered immunity // Plant Cell. 2012. Vol. 24. Pp. 1256-1270.

60. Shahidi-Noghabi S., van Damme E.J.M., Smagghe G. Expression of sambucus nigra agglutinin (SNA-I') from elderberry bark in transgenic tobacco plants results in enhanced resistance to different insect species // Transgenic Res. 2009. Vol. 18. Pp. 249-259. 
61. Гагарина И.Н. Белковый комплекс семян фасоли и испытание биологической активности его компонентов: дис. ... канд. сельхоз. наук. Орел, 2006. 147 с.

62. Патент №2372763 (РФ). Средство для предпосевной обработки семян гороха / Н.Е. Павловская, И.Н. Гагарина, В.В. Роговин, Г.А. Борзенкова, В.М. Муштакова, В.А. Фомина / 2009.

63. Ерохин А.И., Павловская Н.Е. Эффективность совместного применения препаратов на семенах гороха // Земледелие. 2016. №4. С. 17-19.

64. Bebber D.P., Ramotowski M.A.T., Gurr S.J. Crop pests and pathogens move polewards in a warming world. Nat. // Clim. Chang. 2013. Vol. 3. Pp. 985-988.

65. Boyd L.A., Ridout C., O’Sullivan D.M., Leach J.E., Leung H. Plant-pathogen interactions: Disease resistance in modern agriculture // Trends Genet. 2013. Vol. 29. Pp. 233-240.

66. Jin S., Zhang, X., Daniell H. Pinellia ternata agglutinin expression in chloroplasts confers broad spectrum resistance against aphid, whitefly, lepidopteran insects, bacterial and viral pathogens // Plant Biotechnol. 2012. Vol. 10. Pp. 313-327.

67. Евтушенко А.И. Антивирусные свойства лектинов каланхое: изучение и применение лектинов // Уч. зап. Тартус. ун-та. 1989. Вып. 2. 189 с.

68. Рожнова Н.А., Геращенков Г.А., Бабоша А.В. Индукция фитогемагглютинирующей активности в растениях кортофеля in vitro арахидоновой кислотой // Физиология растений. 2002. Т. 49. №4. С. 603-607.

69. Адамо П. 4 группы крови - 4 образа жизни. Минск, 2013. 480 с.

70. Кириченко О.В., Сергиенко В.Г. Фунгитоксичная активность растительных лектинов // Физиология и биохимия культурных растений. 2006. Т. 38. №6. С. 526-534.

71. Шакирова Ф.М., Безрукова М.В. Современные представления о предполагаемых функциях лектинов растений // Журнал общей биологии. 2007. Т. 68. №2. С. 98-114.

72. Максимов И.В., Черепанова Е.А., Яруллина Л.Г., Ахметова И.Э. Выделение «хитинспецифичных» оксидоредуктаз пшеницы // Прикладная биохимия и микробиология. 2005. Т. 41. №6. С. 616-620.

73. Лектины. Влияние на здоровье человека [Электронный ресурс]. URL: http://www.glutenlife.ru/articles/ 4270.html?sphrase_id=1957924

74. Профилактика бактериальных инфекций [Электронный pecypc]. URL: http://medicalfairway.ru/ page_stat.php?ids $=40 \&$ n_word $=$ инфекции

75. Lajolo M.F., Genovese M.I. Nutricional Significanse of lectins and Enzyme Inhibitors from Legumes // Journal of Agricultural and Food Chemistry. 2002. Vol. 50(22). Pp. 6892-6598.

76. Reynoso C.R., González de Mejía E., Loarca P.G. Purification and acute toxicity of a lectin extracted from tepary bean (Phaseolus acutifolius) // Food and Chemical Toxicology. 2003. Vol. 41(1). Pp. 21-27

77. Muraro A., Hoffmann-Sommergruber K., Holzhauser T., Poulsen L.K., Gowland M.H., Akdis C.A.. EAACI food allergy and anaphylaxis guidelines. Protecting consumers with food allergies: understanding food consumption, meeting regulations and identifying unmet needs // Allergy. 2014. Vol. 69(11). Pp. 1464-1472.

78. Nwaru B.I., Hickstein L., Panesar S.S., Muraro A., Werfel T., Cardona V. The epidemiology of food allergy in Europe: a systematic review and meta-analysis // Allergy. 2014. Vol. 69 (1). Pp. 62-75.

79. Geert Houben, Peter Burney, Chun-Han Chan, Rene' Crevel, Anthony Dubois, Roland Faludi, Rinke Klein Entink, Andre' Knulst, teve Taylor, Stefan Ronsmans. Prioritisation of allergenic foods with respect to public health relevance // Allergy. 2016. Vol. 89. Pp. 8-18.

80. Информационная записка ИНФОСАН № 4/2008 - Кодекс Алиментариус Международные пищевые стандарты от 6 июня 2008 г. Совместная программа ФАО/ВОЗ.

81. Соболев С.М., Николаева Т.Н., Григорьева Е.А., Пронин А.В. Роль лектин субстратного распознавания в иммунорегуляторном взаимодействии интерлейкина-2 и $\operatorname{IgG} / /$ Медицинская иммунология. 2010. Т. 12. №1-2. C. 13-20.

82. Heinrich E.L., Welty A.Y., Banner L.R., Oppenheimer S.B. Direct targeting of cancer cells: A multiparameter approach // National Institutes of Health. 2005. Vol. 107(5). Pp. 335-344.

83. Петибская В.С. Соя: химический состав и использование. Майкоп, 2012. 432 с.

84. Nishimura H., Nishimura M., Oda R., Yamanaka K., Matsubara T., Ozaki Y., Sekiya L., Jamada T., Kato Y. Lectins induce resistence to proteases and/or mechanical stimulus in all examined cells-including bone narrow mesenchymal stem cells- on various scaffolds. // Experimental Cell Research. 2004. Vol. 295. Pp.119-127.

85. Pinto L.S., Nagano C.S., Oliveira T.M., Moura T.R., Sampaio A.H., Debray H., Pinto V.P., Dellagostin O.A., Cavada B.S. Purification and molecular cloning of a new galactose-specific lectin from Bauhinia variegata seeds // Journal Biosciencia. 2008. Vol. 33. Pp. 355-363.

86. Lajolo M.F., Genovese M.I. Nutricional Significanse of lectins and Enzyme Inhibitors from Legumes // Journal of Agricultural and Food Chemistry. 2002. Vol. 50(22). Pp. 6892-6598.

87. Канделинская О.Л., Грищенко Е.Р., Обуховская И.П. Мастибротская О.М. Масловский А.Д. Таганович Е.А. Девина Т.Ю. Принькова Т.В. Шман Н.А. Шуканова В.В. Голубков Л.В. Лектины лекарственных растений дикорастущей флоры Беларуси: перспективы использования // Вестник Фонда фундаментальных исследований. 2011. №2. С. 169-182. 
Pavlovskaya N.E., Gagarina I.N.* THE PHYSIOLOGICAL PROPERTIES OF PLANT LECTINS AS A PREREQUISITE FOR THEIR APPLICATION IN BIOTECHNOLOGY

Orel State Agrarian University name N.V. Parahina, ul. Generala Rodina, 69, Orel, 302017, (Russia), e-mail: i-gagarina@list.ru

The purpose of this review is a generalization of the available current data on plant lectins and their characteristic area of use in biotechnology.

The review provides current data on the classification of lectins, the functional role of plant lectins, especially legumes, toxicity, nutritional problems and assumptions used in different areas of biotechnology production, including the creation of means of protection against pathogens in plant and medicine.

Glyco-binding properties and a variety of molecular structures observed in lectins, provided them with a wide range of biological activity, and provided them with the ability to serve as a tool for biotechnological applications.

Plant lectins have a multifunctional role: involved in cell defense reactions against pathogens and herbivorous insects, as well as have an impact on symbiosis with micro-organisms play a key role in establishing symbiotic relationships with rhizobia.

The insecticidal properties of lectins are used in genetic engineering to create stable forms of plants from insect pests, as well as bacterial and viral pathogens.

The interaction of lectins with carbohydrates opens the prospects of their application in critical areas such as immunology, oncology and medicine for the diagnosis and treatment of various diseases. They may also be used as markers for determining the blood groups.

Lectins reduce food and feed value of many cultures and cause allergies.

Keywords: lectins, proteins, hemagglutinins activity, uglevodorodnye proteins, toxic components, grain protein complex, the inhibitory effect.

\section{References}

1. Ana C. Ribeiro, Sara V. Monteiro, Belmira M. Carrapiço, Ricardo B. Ferreira. Molecules, 2014, vol. 19, pp. 20350-20373.

2. Van Dame J.M., Peumans W.J., Pustai A., Bardocz S. Handbook of plant lectins: properties and biomedical applications. Chichester etc.: John Willey and Sons, 1998, p. 451.

3. Rüdiger H., Gabius H., Review J. Glycoconjugate, 2001, vol. 18, pp. 589-613.

4. Sandro Mascena Gomes Filho, Juscélio Donizete Cardoso, Katya Anaya, Edilza Silva do Nascimento, José Thalles Jucelino Gomes de Lacerda, Roberto Mioso, Tatiane Santi Gadelha, Carlos Alberto de Almeida Gadelha. Molecules, 2015, vol. 20, pp. 348-357.

5. Eri Kenmochi, Syed Rashel Kabir, Tomohisa Ogawa, Ryno Naude, Hiroaki Tateno, Jun Hirabayashi, Koji Muramoto. Molecules, 2015, vol. 20, pp. 987-1002.

6. Lektiny [Lectins]. [Elektronnyi resurs]. URL: http://www.horosheezdorovje.ru/lektiny-1/. (in Russ.).

7. Komath S.S., Kavitha M., Swamy M.J. Organic Biomolecular Chemistry, 2006, vol. 4, pp. 973-988.

8. Ignatov V.V. Biologiia (Sorovskii obrazovatel'nyi zhurnal), 1997, no. 2, pp. 15-20. (in Russ.).

9. Kosenko L.V. Fiziologiia rastenii, 2002, vol. 49, no. 6, pp. 859-864. (in Russ.).

10. Kosenko L.V. Fiziologiia rastenii, 2002, vol. 49, no. 5, pp. 718-724. (in Russ.).

11. Kass H. Planta, 1996, vol. 130, no. 2, pp. 169-214.

12. Markov E.Iu., Khavkin E.E. Fiziologiia rastenii, 1983, vol. 30, no. 5. pp. 852-867. (in Russ.).

13. Maria Lígia R., Macedo, Caio F.R., Carolina T. Molecules, 2015, vol. 20, pp. 2014-2033

14. Peumans W.J., van Damme E. Plant Physiol, 1995, vol. 109, pp. 347-352.

15. Van Damme E.J., Lannoo N., Fouquaert E., Peumans W.J. Glycoconj., 2003, vol. 20, pp. 449-460.

16. Van Damme E.J.M., Peumans W.J., Barre A., Rouge P. Crit. Rev. Plant Sci., 1998, vol. 17, pp. 575-692.

17. Antonyuk V.O. Lectins and their stock sources. Lviv, 2005, 554 p.

18. Zhao J.K., Wang H.X., Ng T.B. Toxicon, 2009, vol. 53, pp. 360-366.

19. Li Y.R., Liu Q.H., Wang H.X., Ng T.B. Glycoconjugate Journal, 2010, vol. 27, pp. 259-265

20. Zhang G., Sun J., Wang H., Ng T.B. Phytomedicine, 2010, vol. 17, pp. 775-781.

21. Weiwei Zhang, Guoting Tian, Xueran Geng, Yongchang Zhao, Tzi Bun Ng, Liyan Zhao and Hexiang Wang. Molecules, 2014, vol. 19, pp. 19880-19891.

22. Jun Hirabayashi, Hiroaki Tateno, Toshihide Shikanai, Kiyoko F. Aoki-Kinoshita and Hisashi Narimatsu. Molecules, 2015, vol. 20, pp. 951-973.

23. Aoki-Kinoshita K.F., Bolleman J., Campbell M.P., Kawano S., Kim J.D., Lütteke T., Matsubara M., Okuda S., Ranzinger R., Sawaki H. Biomedical Semantics, 2013, vol. 4, p. 39.

24. Rüdiger H., Gabius, H.J. Fundamentals of Glycosciences, 2009, pp. 301-315.

25. Chrispeels M.J., Raikhel N.V. Plant Cell., 1991, vol. 3, pp. 1-9.

26. Bowles D.J. Planta, 1997, vol. 145, no. 2, p. 193.

27. Kilpatric D.C., Vcomen M.M., Gould A.R. Biochem. J., 1979, vol. 2, p. 215.

28. Iamaleeva A.A. Lektiny rastenii i ikh biologicheskaia rol'. [Plant Lectins and its biological role]. Ufa, 2001,137 p. (in Russ.).

29. Michiels K., van Damme E., Smagghe G. Arch. Insect Biochem. Physiol., 2010, vol. 73, pp. 193-212.

30. Lannoo N., van Damme E.J.M. Acta Gen. Subj., 2010, pp. 190-201.

\footnotetext{
* Corresponding author.
} 
31. Al Atalah B., Smagghe G., van Damme E.J.M. Plant Sci., 2014, pp. 221-222.

32. Roy A., Gupta S., Hess D., Das K.P., Das S. Proteomics, 2014, vol. 14, pp. 1646-1659.

33. Guo P., Wang Y., Zhou X., Xie Y., Wu H., Gao X. Plant Sci., 2013, vol. 211, pp. 17-22.

34. Peumans W.J., Barre A., Hao Q., Rougé P., van Damme E.J.M. Trends Glycosci. Glycotechnol, 2000, vol. 12, Pp. 83-101.

35. Sabine André, Herbert Kaltner, Joachim C. Manning, Paul V. Murphy, Hans-Joachim Gabius Lectins. Molecules, 2015, vol. 20, pp. 1788-1823

36. Sharon N. Acta Anat., 1998, vol. 161, pp.7-17.

37. Rüdiger H., Gabius H.-J. In The Sugar Code. Fundamentals of Glycosciences, 2009, pp. 3-13.

38. Shewry P.R., Napier J.A., Tatham A.S. Plant Cell., 1995, vol. 7, pp. 945-956.

39. Kovalchuk N.V., Melnykova N.M., Musatenko L.I. Biopolym. Cell., 2012, vol. 3, pp. 171-180.

40. Benoist H., Culerrier R., Poiroux G., Segui B., Jauneau A., Van Damme E.J., Peumans W.J., Barre A., Rouge P. J. Leukoc. Biol, 2009, vol. 1, pp. 103-114.

41. Melnykova N.M., Mykhalkiv L.M., Mamenko P.M., Kots S.Ya. Biopolymers and Cell., 2013, vol. 29, no. 5, pp. 357-366

42. Kirichenko E.V., Titova L.V. Prikl. Biokhim. Mikrobiol., 2006, vol. 2, pp. 219-223.

43. Alenkina S.A., Zharkova V.R., Nikitina V.E. Prikl. Biokhim. Mikrobiol., 2007, vol. 6, pp. 653-656.

44. Fernandezdel-Carmen A., Juarez P., Presa S., Granell A., Orzaez D. Biotechnol., 2013, vol. 4, pp. 391-400.

45. Babosh A.V. Zhurnal obshchei biologii, 2008, vol. 69, no. 5, pp. 379-396. (in Russ.).

46. Shakirova F.M., Bezrukova M.V. Zhurnal obshchei biologii, 2007, vol. 68, no. 2, pp. 109-125. (in Russ.).

47. Zhu-Salzman K., Ahn J.E., Salzman R.A., Koiwa H., Shade R.E., Balfe S. Agric. Forest Enthomol., 2003, vol. 4, pp. 317-323.

48. Tinjuangiun P., Loe N.T., Gatehouse A.M.R., Gatehouse J.A., Christou P. Mol. Breed., 2000, vol. 6, pp. $391-399$.

49. Ng T.B. Peptides, 2004, vol. 25, pp. 1215-1222.

50. Gomes V.M., Okorokov L.A., Rose T.L., Fernandes K.V.S., Xavier-Filho J. Biochim. Biophys. Acta., 1998, pp.207-216.

51. Ribeiro A., Catarino S., Ferreira R.B.F. Carbohyd. Res., 2012, pp. 206-210.

52. Renata de Oliveira Dias, Leandro dos Santos Machado, Ludovico Migliolo, Octavio Luiz Franco. Molecules, 2015, vol. 20, pp.519-541.

53. Miyakawa T., Hatano K.-I., Miyauch, Y., Suwa Y.-I., Sawano Y., Tanokura M. Plant Physiol., 2014, vol. 166, pp.766-778.

54. Ang A.S.W., Cheung R.C.F., Dan X., Chan Y.S., Pan W., Ng T.B. Appl. Biochem. Biotechnol., 2014, vol. 172, pp. 672-686.

55. Kanzaki H., Saitoh H., Takahashi Y., Berberich T., Ito A., Kamoun S., Terauchi R. Planta, 2008, vol. 228, pp. $977-987$.

56. Bouwmeester K., de Sain M., Weide R., Gouget A., Klamer S., Canut H., Govers F. The lectin receptor kinase LecRK-I.9 is a novel Phytophthora resistance component and a potential host target for a RXLR effector. PLoS Pathog, 2011, $327 \mathrm{p}$.

57. Huang P., Ju H.-W., Min J.-H., Zhang X., Kim S.-H., Yang K.-Y., Kim C.S. Plant Sci., 2013, vol. 203, pp. $98-106$.

58. Singh P., Chien C.-C., Mishra S., Tsai C.-H., Zimmerl L. The arabidopsis lectin receptor kinase-VI. 2 is a functional protein kinase and is dispensable for basal resistance to Botrytis cinerea. Plant Signal. Behav, 2012, $611 \mathrm{p}$.

59. Singh P., Kuo Y.-C., Mishra S., Tsai C.-H., Chien C.-C., Chen C.-W., Desclos-Theveniau M., Chu P.-W., Schulze B., Chinchilla D. Plant Cell., 2012, vol. 24, pp. 1256-1270.

60. Shahidi-Noghabi S., van Damme E.J.M., Smagghe G. Transgenic Res., 2009, vol. 18, pp. 249-259.

61. Gagarina I.N. Belkovyi kompleks semian fasoli i ispytanie biologicheskoi aktivnosti ego komponentov: dis. ... kand. s. $-k h . n$. [The protein complex of bean seeds and test the biological activity of its components: dis. ... Cand. agricultural Sciences]. Orel, 2006, 147 p. (in Russ.).

62. Patent 2372763 (RU). 2009. (in Russ.).

63. Erokhin A.I., Pavlovskaia N.E. Zemledelie, 2016, no. 4, pp. 17-19. (in Russ.).

64. Bebber D.P., Ramotowski M.A.T., Gurr S.J. Clim. Chang., 2013, vol. 3, pp. 985-988.

65. Boyd L.A., Ridout C., O’Sullivan D.M., Leach J.E., Leung H. Trends Genet., 2013, vol. 29, pp. 233-240.

66. Jin S., Zhang, X., Daniell H. Plant Biotechnol., 2012, vol. 10, pp. 313-327.

67. Evtushenko A.I. Uch. zap. Tartus. un-ta. 1989, no. 2, p. 189. (in Russ.).

68. Rozhnova N.A., Gerashchenkov G.A., Babosha A.V. Fiziologiia rastenii, 2002, vol. 49, no. 4, pp. $603-607$. (in Russ.).

69. Adamo P. 4 gruppy krovi - 4 obraza zhizni. [4 blood groups - 4 lifestyle]. Minsk, 2013, 480 p. (in Russ.).

70. Kirichenko O.V., Sergienko V.G. Fiziologiia i biokhimiia kul'turnykh rastenii, 2006, vol. 38, no. 6, pp. 526-534. (in Russ.).

71. Shakirova F.M., Bezrukova M.V. Zhurnal obshchei biologii, 2007, vol. 68, no. 2, pp. 98-114. (in Russ.).

72. Maksimov I.V., Cherepanova E.A., Iarullina L.G., Akhmetova I.E. Prikladnaia biokhimiia i mikrobiologiia, 2005, vol. 41, no. 6, pp. 616-620. (in Russ.).

73. Lektiny. Vliianie na zdorov'e cheloveka [Lectins. Impact on Human Health]. [Elektronnyi resurs]. URL: http://www.glutenlife.ru/articles/4270.html?sphrase_id=1957924 (in Russ.).

74. Profilaktika bakterial'nykh infektsii [Prevention of bacterial infections]. [Elektronnyi resurs]. URL: http://medicalfairway.ru/page_stat.php?ids=40\&n_word=инфекции (in Russ.).

75. Lajolo M.F., Genovese M.I. Journal of Agricultural and Food Chemistry, 2002, vol. 50(22), pp. 6892-6598. 
76. Reynoso C.R., González de Mejía E., Loarca P.G. Food and Chemical Toxicology, 2003, vol. 41(1), pp. 21-27

77. Muraro A., Hoffmann-Sommergruber K., Holzhauser T., Poulsen L.K., Gowland M.H., Akdis C.A. Allergy, 2014, vol. 69(11), pp. 1464-1472.

78. Nwaru B.I., Hickstein L., Panesar S.S., Muraro A., Werfel T., Cardona V. Allergy, 2014, vol. 69 (1), pp. $62-75$.

79. Geert Houben, Peter Burney, Chun-Han Chan, Rene' Crevel, Anthony Dubois, Roland Faludi, Rinke Klein Entink, Andre' Knulst, teve Taylor, Stefan Ronsmans. Allergy, 2016, vol. 89, pp. 8-18.

80. Informatsionnaia zapiska INFOSAN № 4/2008 - Kodeks Alimentarius Mezhdunarodnye pishchevye standarty ot 6 iiunia 2008 g. Sovmestnaia programma FAO/VOZ. [INFOSAN Information Note number 4/2008 - International Codex Alimentarius food standards, you're on June 6, 2008 Joint FAO / WHO program.]. (in Russ.).

81. Sobolev S.M., Nikolaeva T.N., Grigor'eva E.A., Pronin A.V. Meditsinskaia immunologiia, 2010, vol. 12, no. 1-2, pp. 13-20. (in Russ.).

82. Heinrich E.L., Welty A.Y., Banner L.R., Oppenheimer S.B. National Institutes of Health, 2005, vol. 107(5), pp. 335-344.

83. Petibskaia V.S. Soia: khimicheskii sostav i ispol'zovanie. [Soybean: chemical composition and use]. Maikop, 2012, 432 p. (in Russ.).

84. Nishimura H., Nishimura M., Oda R., Yamanaka K., Matsubara T., Ozaki Y., Sekiya L., Jamada T., Kato Y. Experimental Cell Research, 2004, vol. 295, pp.119-127.

85. Pinto L.S., Nagano C.S., Oliveira T.M., Moura T.R., Sampaio A.H., Debray H., Pinto V.P., Dellagostin O.A., Cavada B.S. Journal Biosciencia, 2008, vol. 33, pp. 355-363.

86. Lajolo M.F., Genovese M.I. Journal of Agricultural and Food Chemistry, 2002, vol. 50(22), pp. 6892-6598.

87. Kandelinskaia O.L., Grishchenko E.R., Obukhovskaia I.P. Mastibrotskaia O.M. Maslovskii A.D. Taganovich E.A. Devina T.Iu. Prin'kova T.V. Shman N.A. Shukanova V.V. Golubkov L.V. Vestnik Fonda fundamental'nykh issledovanii, 2011, no. 2, pp. 169-182. (in Russ.).

Received May 12, 2016

Revised December 1, 2016 
